\title{
Business Simulator as a Business Teaching-Learning Strategy
}

\author{
Melissa Velasco-Saltos ${ }^{1}$, Juliana Mesías-Vargas ${ }^{1} \&$ Patricio Medina-Chicaiza ${ }^{2}$ \\ ${ }^{1}$ Business Engineer, Universidad Técnica de Ambato, Ambato-Ecuador \\ ${ }^{2}$ Master in Digital Marketing and Electronic Commerce and in Information Technology, Pontificia Universidad \\ Católica del Ecuador; Professor of the School of Systems Engineering, Universidad Técnica de Ambato; \\ Professor of the Faculty of Administrative Sciences, Ambato, Ecuador \\ Correspondence: Patricio Medina-Chicaiza, Technical University of Ambato. Ambato, Ecuador.
}

Received: December 10, 2019

Accepted: January 8, 2020

Online Published: January 16, 2020

doi:10.5539/ibr.v13n2p41

URL: https://doi.org/10.5539/ibr.v13n2p41

\begin{abstract}
This research proposes the use of business simulators as a business teaching-learning strategy in the Business Administration Degree in a Higher Education Institution in Ecuador. The problematic situation that is evident is that the modules or subjects related to business negotiation are dictated in a theoretical way, but an adequate practical teaching process is not carried out, which triggers a deficit in the development of skills adjusted to the academic performance of the students and future professionals. For the elaboration of the content, documents in Spanish and English were registered in databases such as Springer, Scopus, Scielo, Web of Science, Redalyc, EBSCO among others Interviews and direct observation were also used, with which evidence was found under the use index of the technological tool. Finally, 5 stages were proposed for the elaboration of the strategy: diagnosis, preparation, planning, execution, evaluation, and control.
\end{abstract}

Keywords: learning, business, teaching, strategy, simulator, business simulator, technology

\section{Introduction}

Universities, public and private polytechnic schools, duly valued and accredited, are considered Higher Education Institutions (HEIs) of the Republic of Ecuador in accordance with article 14 of the Organic Law of Higher Education (LOES) (Consejo de Educación Superior [CES], 2018). Therefore, according to art. 159 of the LOES the HEIs are academic communities with their own legal status, essentially pluralistic and open to all the currents and forms of universal thought exposed in a scientific way (CES, 2018). These types of institutions are intended to train professionals highly qualified through research at various levels of knowledge to solve the different problems that arise in the country and contribute to its development.

Adding to this, according to article 5 of the LOES (CES, 2018), it is mentioned in literal $b$ that one of the rights of the student is to access a quality and relevant higher education, which allows them to start an academic and/or professional career with equal opportunities. Therefore, it is important and essential to generate teaching strategies that encourage the development of skills and competencies in the people involved.

In reference to the above, the strong technological evolution, and the progressive demand for higher education to have professionals who have deep and meaningful learning, (Garizurieta, Muñoz, Otero, \& González, 2018) have inspired universities to have various teaching-learning tools so that different strategies and activities are implemented every day for students to achieve their skills through the use of information technologies. Taking this into consideration, it is clear that computer-assisted learning such as business simulators is important since it would allow the Business Administration student, or of a related career, to make business decisions under numerous variables that are manipulated according to various criteria, which allows consolidating their knowledge for the future in real environments.

Business simulators play an important role in the formation and training process since they allow the creation of a virtual business environment so that students have the opportunity to participate in activities according to the business process of a specific organization or area (Ballina \& Marín, 2007). From the point of view of Garizurieta et al. (2018), business simulators are an educational learning tool designed to provide active teaching to solve problems and encourage students to analyze and learn that the success or failure of the virtual reality depends on the most important decisions they make in terms of price, investments, and marketing, among other things. Likewise, the authors Guzmán and Moral (2018) mention that this type of tool implemented in university business 
education has been transformed into teaching strategies, in particular when applying theoretical knowledge, reviewing the impact of decisions and minimizing the risks that would lead to mistakes in real situations. Therefore, the use of business simulators is key for teachers in the teaching process, as well as for students in their training and learning, when developing their skills and abilities in the business process that foster lasting learning so that the students believe in their projections.

In this way, the problematic situation that is evidenced through visits made to 4 HEIs of the city of Ambato-Ecuador is that the modules or subjects related to business negotiation are dictated in a theoretical way, but an adequate practical teaching process is not carried out, which triggers a deficit in the development of skills adjusted to the current job performance of students and future professionals. In addition, it is evident that the teaching staff is not trained to present an appropriate teaching process that involves the use of tools that make it possible to take advantage of administrative-theoretical knowledge in practice. Consequently, the direct beneficiaries are teachers, students, and HEIs, when using business simulators as a tool in the teaching-learning process and business development. On the other hand, companies that will have competent and proactive professionals are indirect beneficiaries.

With this reference, this paper aims to propose the use of business simulators as a business teaching-learning strategy in the Business Administration Degree in an HEI.

\section{Methodology}

The study has been structured through research and bibliographic compilation in Spanish and English, on data basis, such as: Springer, Scopus, Scielo, Web of Science, Redalyc, Google Scholar, EBSCO as well as academic websites, theses repositories and studies from national organizations, which allowed the review and analysis of a series of relevant documents. Based on the information gathered, the use of the theoretical methods, among them, analysis-synthesis, which allowed reaching personal conclusions on the matter. It has been inductive-deductive in the process of understanding what a simulator is, business simulator and its relationship in the process of teaching-learning in the administrative field.

Interviews were conducted as a base to obtain information, where structured questions were made for three groups of people: career coordinators, teachers and students, for the three HEIs visited.

\section{Participants}

Ambato-Ecuador covers 4 HEIs, 3 private and 1 public institution (CES, 2018). This study sampled 3 out of the 4 , discarding 1 of the private institutions since they do not possess data or experience in the subject matter.

The people surveyed are described below:

Table 1. Sample

\begin{tabular}{|c|c|c|c|}
\hline HEI & $\begin{array}{ll}\text { Business } & \text { Administration } \\
\text { Coordinators } & \end{array}$ & $\begin{array}{l}\text { Faculty with higher studies } \\
\text { in Business }\end{array}$ & $\begin{array}{l}\text { Business Administration } \\
\text { Students between 4th and 6th } \\
\text { semester }\end{array}$ \\
\hline Private 1 & 1 & 3 & 25 \\
\hline Private 2 & 1 & 7 & 20 \\
\hline Public 1 & 1 & 5 & 35 \\
\hline
\end{tabular}

Source: own elaboration

\section{Procedure}

After the bibliographical revision, the following steps took place: First, a brief investigation was made into HEIs registered in the city of Ambato, Ecuador. Second, the HEIs offering Business Administration degrees were selected and contacted to diagnose the use of business simulators in the teaching-learning process. Then, directors of the Business Administration Board of each institution were interviewed aiming to find the courses in which one could use technological tools. Next, teachers were also interviewed regarding whether they actually use these tools in their courses. Lastly, students were surveyed to find out how to manipulate business simulators in the development of their learning. A bibliographic search was conducted to find strategies linked to the use of business simulators. A strategy was built. And finally, the phases and activities of the proposed strategy were socialized.

\section{Results}

The topics addressed in this section are: Emergence and development of business simulators, general characteristics, student-teacher benefits, classification and comparative analysis of business simulators.

\section{Emergence and development of business simulators}

A historical background analysis of business simulators is presented chronologically. 
Table 2. Evolution of business simulators

\begin{tabular}{|c|c|c|c|}
\hline Year & Author & Tool development & Description \\
\hline $\begin{array}{l}3000 \\
\text { a.C }\end{array}$ & $\begin{array}{l}\text { Garizurieta Et } \\
\text { al. (2018) }\end{array}$ & Board games in China. & $\begin{array}{l}\text { Game on boards in which each participant had to } \\
\text { create strategies to get the most chips from his } \\
\text { opponent. }\end{array}$ \\
\hline 1934 & $\begin{array}{l}\text { Garizurieta Et } \\
\text { al. (2018) }\end{array}$ & $\begin{array}{l}\text { Monopoly emerges as an approach to } \\
\text { business simulation games. }\end{array}$ & $\begin{array}{l}\text { Game board that recreates a city, in which the } \\
\text { purchase and sale of real estate is carried out. }\end{array}$ \\
\hline 1956 & $\begin{array}{l}\text { Ruíz \& Ruíz } \\
\text { (2013) }\end{array}$ & $\begin{array}{l}\text { Development of the first practical and } \\
\text { successful business simulation game } \\
\text { called "Top Management Decision } \\
\text { Simulation", which was widely used. }\end{array}$ & $\begin{array}{l}\text { It was the first computerized simulator to make } \\
\text { administrative decisions as a team through a program } \\
\text { that processed its provisions and presented quarterly } \\
\text { financial reports. }\end{array}$ \\
\hline 1957 & $\begin{array}{l}\text { Ruíz \& Ruíz } \\
\text { (2013) }\end{array}$ & $\begin{array}{l}\text { The consulting firm McKinsey y Cia. } \\
\text { developed the business administration } \\
\text { simulator to use in its business seminars. }\end{array}$ & $\begin{array}{l}\text { It offered the option of handling simplified } \\
\text { accounting and mathematical operations such as } \\
\text { sales prices, production volumes etc., through a } \\
\text { computerized program. }\end{array}$ \\
\hline 1957 & $\begin{array}{l}\text { Ruíz \& Ruíz } \\
(2013)\end{array}$ & $\begin{array}{l}\text { The University of Washington became } \\
\text { the first to use a business simulation } \\
\text { game in its class (Business Policy). }\end{array}$ & $\begin{array}{l}\text { It allowed students to make strategic management } \\
\text { oriented decisions based on external economic } \\
\text { factors. }\end{array}$ \\
\hline 1963 & $\begin{array}{l}\text { LABSAG } \\
(2018)\end{array}$ & $\begin{array}{l}\text { In Latin America, the first University to } \\
\text { use simulations was the Monterrey } \\
\text { Institute of Technology and Higher } \\
\text { Education, shortly after organizing the } \\
\text { first Master in Business Administration. }\end{array}$ & $\begin{array}{l}\text { Simulation programs were increasingly inserted in } \\
\text { the educational area as a tool for teachers and } \\
\text { students. }\end{array}$ \\
\hline 1969 & $\begin{array}{l}\text { LABSAG } \\
(2018)\end{array}$ & $\begin{array}{l}\text { Graham and Gray publish a description } \\
\text { of } 180 \text { computerized simulators. }\end{array}$ & $\begin{array}{l}\text { This large number of simulators focused on different } \\
\text { areas such as aerospace, advertising, sales, banking, } \\
\text { agribusiness, among others. }\end{array}$ \\
\hline 1974 & $\begin{array}{l}\text { LABSAG } \\
(2018)\end{array}$ & Schriesham located 400 simulators. & $\begin{array}{l}\text { Part of this growth was the accreditation standard } \\
\text { imposed by the American Association of Collegiate } \\
\text { Schools of Business (AACSB) by demanding that the } \\
\text { MBA's curriculum should conclude with an } \\
\text { integrative Strategy and Policy course, ideal for the } \\
\text { use of simulators and where its usefulness has been } \\
\text { concentrated. }\end{array}$ \\
\hline 1989 & $\begin{array}{l}\text { LABSAG } \\
(2018)\end{array}$ & $\begin{array}{l}\text { One of the most complex simulations } \\
\text { used in the Ace Exercise of the North } \\
\text { Atlantic Organization appears in which } \\
3,000 \text { commanders participated in the } \\
\text { decision-making process for eleven days } \\
\text { in a row. }\end{array}$ & $\begin{array}{l}\text { The simulations grew especially in complexity, using } \\
\text { them to make decisions in military and flight tasks. }\end{array}$ \\
\hline 1996 & $\begin{array}{l}\text { LABSAG } \\
(2018)\end{array}$ & $\begin{array}{l}\text { A survey conducted by Anthony J. Faria, } \\
\text { found } 11,386 \text { university instructors using } \\
\text { simulators in American universities, and } \\
7,808 \text { companies that used simulators in } \\
\text { the training of their staff. }\end{array}$ & $\begin{array}{l}\text { As the number of simulators grew, their advocates } \\
\text { also increased thanks to the variety of fields and } \\
\text { topics related to business and administration. }\end{array}$ \\
\hline 1998 & $\begin{array}{l}\text { Ruíz \& Ruíz } \\
(2013)\end{array}$ & $\begin{array}{l}\text { Tecnológico de Monterrey Campus } \\
\text { Estado de México implemented a } \\
\text { simulation center. }\end{array}$ & $\begin{array}{l}\text { The technological tool was spreading more and } \\
\text { more in the educational field allowing its students to } \\
\text { achieve better training and education in the field of } \\
\text { business. }\end{array}$ \\
\hline 2003 & $\begin{array}{l}\text { LABSAG } \\
(2018)\end{array}$ & $\begin{array}{l}\text { LABSAG implemented a laboratory with } \\
3 \text { business simulators to manage the flow } \\
\text { of students and participants online. }\end{array}$ & $\begin{array}{l}\text { The simulators were developed, modified and } \\
\text { augmented with an "upgrade" to be able to serve } \\
\text { many university users and executives online. }\end{array}$ \\
\hline 2019 & & $\begin{array}{l}\text { Ceo-Vitual, Company Game, and Cesim, } \\
\text { are some of the companies that currently } \\
\text { offer a variety of business simulators. }\end{array}$ & $\begin{array}{l}\text { These types of virtual platforms offer their service } \\
\text { online. Their simulators have an extensive range of } \\
\text { business environments from less to greater difficulty } \\
\text { according to user preference and an increasingly } \\
\text { realistic management experience. }\end{array}$ \\
\hline
\end{tabular}

Source: own elaboration based on reviewed literature

It is evident that business simulators have been part of human life since ancient times, since they need to constantly act in the face of the various events that arise and consequently make decisions. Therefore, these types of tools evoke their principles; subsequently they grow in quantity, complexity and technology. Thus, due to their didactic use, these are integrated into the field of education, especially university as a key and strategic factor for the process of teaching-learning and better business development. There are online business simulators nowadays and thanks to the Internet there is a wide range of these instruments, which offer a variety of business environments with a degree of difficulty to choose according to the user's previous knowledge, accompanied by an increasingly realistic experience. 


\section{General characteristics of business simulators}

Using the words of Lainema (1999), the use of business simulators complement the theoretical material and act as a final stage of mastery during training. As one of the most active training methods, a business simulation activates participants' thinking and behavior, incentives a high degree of participation in the game process, and mandates interaction between the participants and the game materials.

According to Ruíz \& Ruíz (2013), the business simulator is a dynamic training tool, useful for academic development that allows the individuals involved obtaining a practical and comprehensive learning. Users must be placed in a context that imitates reality in a way that they can experience without risks, and their learning contributes to raising their formative quality during the process.

Ochoa, González, Moriel, Arreola \& García (2017) consider that learning with business simulators helps in decision-making. It is relatable to different real-life scenarios and the complexity of daily work in organizations, and common activities in companies: industrial, goods and services, educational and others. These characteristics can be coupled to users' needs, without neglecting the range of variables that are part of the decisions that must be made during the simulation (e.g., sales price, production volumes, inventory control, short and long term investments, loans, time management, points of sale, etc.) according to the type of business that is simulated.

Therefore, the different business topics presented in games become a powerful tool for universities that seek to improve teaching-learning dynamics, such as organizations that intend to train staff or simply business enthusiasts who want to expand their training, knowledge and business skills.

\section{Benefits of business simulators for students and teachers in HEIs}

Table 3. Benefits of business simulators

\begin{tabular}{|c|c|}
\hline \multicolumn{2}{|c|}{ Benefits of business simulators } \\
\hline Students & Teachers \\
\hline $\begin{array}{l}\text { Students can use the information obtained from changing and } \\
\text { complex environments to improve their ability to assimilate } \\
\text { and organize it. }\end{array}$ & $\begin{array}{l}\text { It gives them the opportunity to create new and dynamic work } \\
\text { environments in class, so that students pay better attention. }\end{array}$ \\
\hline $\begin{array}{l}\text { It motivates their focus in acquiring theoretical knowledge } \\
\text { that will be very useful when starting a business simulation. }\end{array}$ & $\begin{array}{l}\text { They can monitor each of the activities and decisions that the } \\
\text { work teams are carrying out from their computers. }\end{array}$ \\
\hline Ability to work effectively as a team. & Create an appropriate evaluation system. \\
\hline $\begin{array}{l}\text { They can experience real situations in the business } \\
\text { environment so that when faced with them in their working } \\
\text { life they can relate to their learning from the simulations. }\end{array}$ & $\begin{array}{l}\text { The instructor's role in the simulations will allow keeping } \\
\text { students up to date with information regarding the activities } \\
\text { that will be carried out in the games, which will enrich their } \\
\text { technological and business knowledge. }\end{array}$ \\
\hline $\begin{array}{l}\text { Ability to plan, create strategies and make high-risk decisions, } \\
\text { just as a manager or high-level business official does. }\end{array}$ & $\begin{array}{l}\text { It allows the theoretical contents to be selected in a timely } \\
\text { manner, according to the activities that will be carried out in } \\
\text { the simulator. }\end{array}$ \\
\hline $\begin{array}{l}\text { They contribute to learn from mistakes and critically analyze } \\
\text { the possible consequences of the solutions taken (Joldoshov } \\
\text { \& Sayakbaeva, 2018). }\end{array}$ & $\begin{array}{l}\text { The teachers act as coordinators in the different activities that } \\
\text { must be planned in the simulator before starting a simulation } \\
\text { so they will have the power to choose game variables and } \\
\text { scenarios. }\end{array}$ \\
\hline $\begin{array}{l}\text { The administrative roles of each team member are assumed } \\
\text { with responsibility and seriousness. }\end{array}$ & $\begin{array}{l}\text { Creates an evolution in the teaching-learning methodology } \\
\text { through experiences that resemble reality. }\end{array}$ \\
\hline $\begin{array}{l}\text { Students face competitive environments because they must } \\
\text { deal with other companies (work teams) and their decisions } \\
\text { keep them at the top of the market, thus improving their } \\
\text { proficiency (Alqirem \& Al Omoush, 2018). }\end{array}$ & $\begin{array}{l}\text { Make the most of students' knowledge, contributions and } \\
\text { interaction in such a way that the class becomes a business } \\
\text { incubator. }\end{array}$ \\
\hline Provides ability to perform different forms of leadership. & $\begin{array}{l}\text { It dynamizes group relationships, enhances participatory and } \\
\text { collaborative work in the classroom. }\end{array}$ \\
\hline $\begin{array}{l}\text { It helps students to show management skills as an } \\
\text { entrepreneur: to set long-term goals and to use beneficial } \\
\text { opportunities. }\end{array}$ & $\begin{array}{l}\text { According to Musarskaya \& Kooli (2017), the simulators } \\
\text { promote innovative teaching methods and improve teamwork } \\
\text { skills. }\end{array}$ \\
\hline $\begin{array}{l}\text { According to León \& Cañas (2014), its benefit, over other } \\
\text { didactic methodologies, is that it allows them to learn through } \\
\text { interactive processes in which they use their knowledge and } \\
\text { information provided, to make comprehensive business } \\
\text { decisions, obtain continuous feedback on the results of these } \\
\text { decisions and improve their learning in trial and error } \\
\text { processes. }\end{array}$ & \\
\hline $\begin{array}{l}\text { It manages to bring students closer to economic realities } \\
\text { where they can make decisions and assess their results until } \\
\text { they become aware of the circumstantial factors that affect } \\
\text { business efficiency (Musarskaya \& Kooli, 2017). }\end{array}$ & \\
\hline
\end{tabular}


Source: own elaboration

\section{Business simulators classification}

According to Garzón (2012), business simulators can be classified as follows:

General: When it comes to demonstrating the use of corporate strategies and key decisions that the company's management must make.

Specific: When they focus on the simulation of activities in a particular area of a company, such as: Marketing, finance and production.

\section{Comparative analysis of business simulators}

Business simulation has become an important instructional product, as it allows participants to integrate and apply accumulated knowledge using a systems approach to master decision-making skills and act as managers in a simulated, yet realistic, business environments.

An exhaustive research is conducted in bibliographic sources to determine some of the business simulators that can be used in this study. Chavarro \& Ramírez (2009) deduce that virtual CEO is one of the best known general business simulators in the market since the user experience, under the company's direction, analyzes all kinds of variables and administrative areas that the tool offers for proper decision making. Meanwhile, Mendoza (2016) considers that Global2020, a CompanyGame platform simulator widely used in educational and business training, recognizes key variables, such as the functional areas of the company. Finally Garzón (2012) declares that LABSAG offers the process of administration, installation, training and advice in the use of business simulators for the development of managerial skills and abilities as a fully installed integral platform, in a dedicated way for the exclusive use of a University in several careers and departments.

These three types of internationally recognized virtual business simulators are compared:

Table 4. Comparative analysis of business simulators

\begin{tabular}{|c|c|c|}
\hline CEO-VIRTUAL & GIOBAL2020 & TEMPOMATIC \\
\hline Virtual platform: Ceo-Virtual & Virtual platform: CompanyGame & Virtual platform: LABSAG \\
\hline Payment & Payment & Payment \\
\hline $\begin{array}{l}\text { It works online via a link shared to } \\
\text { competitors by coordinators. }\end{array}$ & $\begin{array}{l}\text { It works online via a link shared to } \\
\text { competitors by coordinators. }\end{array}$ & $\begin{array}{l}\text { It works online or through installed } \\
\text { software on any PC. }\end{array}$ \\
\hline $\begin{array}{l}\text { Modality: competitive team, competitive } \\
\text { individual }\end{array}$ & $\begin{array}{l}\text { Modality: competitive team, } \\
\text { competitive individual }\end{array}$ & $\begin{array}{l}\text { Modality: competitive } \\
\text { competitive individual }\end{array}$ \\
\hline $\begin{array}{l}8 \text { teams with an unlimited number of } \\
\text { participants per team. }\end{array}$ & Maximum of 25 participants & Unlimited participants \\
\hline Sector: Various & Sector: Services & isumer goods \\
\hline Simulation duration: 6 periods & Simulation duration: 16 hours & Simulation duration: 3 months \\
\hline $\begin{array}{cl}\text { Topics: } & \\
\text { - } & \text { Strategic planning } \\
& \text { Economic-financial } \\
\text { - } & \text { Accounting } \\
\text { - } & \text { Personnel management } \\
\text { - } & \text { Marketing management }\end{array}$ & $\begin{array}{cl}\text { Topics: } & \\
\cdot & \text { Internationalization strategy. } \\
\text { - } & \text { Economic-financial } \\
& \text { management } \\
\text { • } & \text { Operation management } \\
\text { HR management. }\end{array}$ & $\begin{array}{cl}\text { Topics: } & \\
\text { - } & \text { Strategic planning } \\
\text { - } & \text { Economic-financial } \\
& \text { management. } \\
\text { - } & \text { Sales management } \\
\text { - } & \text { Personnel management } \\
\text { Operation management }\end{array}$ \\
\hline
\end{tabular}

It recreates competitive market behavior, It recreates the competitive scenario of based on the understanding of basic five companies producing textile market laws when investing in it. articles of clothing, which must Participants occupy the role of business compete with each other. All users start managers who try to improve their profits the simulation in the same competitive without losing sight of the interest in the position.

community and the environment.

$\begin{array}{ll}\text { Decisions are made regarding: } \\ \text { - } & \text { Sale price } \\ \text { • } & \text { Production Level } \\ \text { - } & \text { Investeting Investment } \\ \text { - } & \text { Investment in R\&D } \\ \text { - } & \text { Loan request }\end{array}$

Requires license to use
There is only one coordinator (teacher)
Participants will manage an industrially assembled consumer goods company, handling all managerial functions, with a long-term perspective.

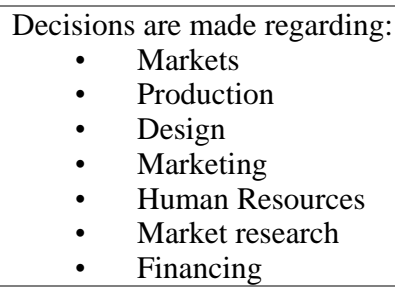

There is a coordinator or coordinators There is only one coordinator (teacher) 
who will have control over different characteristics of the simulation.

Price:

Standard plan: $\$ 2,100$ for 3 months,

$\$ 3,360$ for 6 months, and $\$ 4,999$ for 12 months.

Corporate plan: $\$ 3,600$ for 6 months, $\$ 5,376$ for 12 months, and $\$ 7,999$ for 24 months.

Payment methods:

Credit card, electronic transfer (has a 5\% discount), or cash through rapipago or easy payment. who will have control over different characteristics of the simulation.

Price: The company does not provide this type of information if a formal request from an institution that is really interested in acquiring the software.

\section{Payment methods:}

-Sponsorship code: alphanumeric code delivered by CompanyGame and which allows to register courses,

-Course payment: Access to a credit card payment gateway to pay the course fee, or

-Student payment: when registering, students must pay an amount using a credit card payment gateway to pay the course fee. who will have control over different characteristics of the simulation.

Price: Light version with 5 simulators, includes the simulator "TEMPOMATIC" and has a cost of $\$ 35,000$ for 5 years.

Full version with 8 simulators, includes the simulator "TEMPOMATIC" and has a cost of $\$ 40,000$ for 5 years.

Payment methods:

Conclusion of a contract of sale in which the contracting party covers the payment in a single exhibition by electronic transfer to the account notified by the supplier.

Sources: (CEO-VIRTUAL, 2014); (Global2020, 2015); (Michelsen Consulting, 2018); (Michelsen Consulting , 2019)

The main characteristics of business simulators that could be considered prior to their acquisition are shown in table 4, given that choosing a tool like such in educational processes guarantees the growth and improvement of pre-professionals skills. After a brief evaluation, the CEO-VIRTUAL technology tool is established as a better option since it is a simulator that reproduces the behavior of a competitive market with complete business topics, in which its participants make decisions of all kinds, for which they must possess extensive administrative theoretical knowledge. Moreover, its price and payment method are accessible to HEIs.

\section{Building the strategy}

Prior to building the strategy, several authors' criteria are analyzed, including Orellana \& Montenegro (2015) who structure three comprehensive stages in the implementation of business simulators in the teaching-learning process: preparation, planning, and execution and evaluation. Tejada, Viñas, \& Arcos (2016) establish the following phases: Planning, integration, detection of areas of opportunity, diagnosis, design-development, and evaluation. Barcia \& Carvajal (2015) consider that the choice of appropriate teaching elements for each situation and design of good educational interventions are abbreviated in a series of learning activities aimed at students and appropriate to their characteristics, these are: objectives, contents, methods (techniques), resources (means), and evaluation. Likewise, Da Cruz (2017) proposes the following phases: diagnosis, planning, organization-execution, control and evaluation. However, the last two authors make their contributions of phases and activities in a general way as part of the teaching-learning process in higher education that is certainly linked and contributes to this proposal. Five phases are, thus, proposed: diagnosis, preparation, planning, execution, evaluation and control.

\section{Stage 1. Diagnosis of HEI conditions}

- Establish the profile of the teacher in charge of the business simulation subject according to the HEI regulations. The following profile is proposed:

Table 5. Recommended teaching profile

\begin{tabular}{|c|c|c|c|}
\hline \multirow{5}{*}{$\begin{array}{l}\text { Job title } \\
\text { College } \\
\text { professor }\end{array}$} & \multicolumn{3}{|c|}{ Requirements } \\
\hline & Instruction & Expertice & Technical competencies \\
\hline & LEVEL: $\quad$ Pre-degree & Teaching & Management of \\
\hline & Post-degree & Administration & Tools in particular (bu \\
\hline & KNOWLEDGE & & simulators) \\
\hline & $\begin{array}{l}\text { Business Administration or } \\
\text { other related area }\end{array}$ & $\begin{array}{l}\text { Experience in the workplace and } \\
\text { business. }\end{array}$ & \\
\hline
\end{tabular}

Source: own elaboration

- Verify the current conditions of each institution's technological infrastructure.

- Determine the existence of a computer program in business simulation.

- Know the teachers skills in the use of business and teaching simulators by staff in charge. 


\section{Stage 2. Preparation of previous conditions}

- Select the teacher who meets the appropriate profile by the Commission in charge.

- Train teachers on business simulators.

- Analyze the knowledge of trained teachers through a data collection instrument.

- Propose new training topics.

- Adapt the course's laboratories.

- Acquire the computer program. See table 4.

\section{Stage 3. Planning}

- Prepare the units and topics by the selected teacher. The following are suggested:

Table 6. Units and content

\begin{tabular}{|c|c|}
\hline UNITS & CONTENT \\
\hline Unit 1. Introduction to business simulation. & $\begin{array}{l}\text { 1.1. History of business simulation. } \\
\text { 1.2. Concepts and definitions of business simulators. } \\
\text { 1.3. Types and characteristics of business simulators. } \\
\text { 1.4. Business simulation and its relationship in the business } \\
\text { environment. }\end{array}$ \\
\hline Unit 2. Introductory framework. & $\begin{array}{l}\text { 2.1. Management decision making. } \\
\text { 2.2. Economic-financial, personnel, marketing decisions among others. } \\
\text { 2.3. Strategic management. } \\
\text { 2.4. Teamwork. }\end{array}$ \\
\hline Unit 3. Computational tools. & $\begin{array}{l}\text { 3.1. Introduction of the simulator (software) acquired. } \\
\text { 3.2. Work environment. Main options, access menus, action buttons. } \\
\text { 3.3. Data entry, rules, conditions, basic simulation scenarios. } \\
\text { 3.4. Explanation of the variables displayed by the simulator. }\end{array}$ \\
\hline Unit 4. Reports and decision-making. & $\begin{array}{l}\text { 4.1. Generation of graphics and consolidates. } \\
\text { 4.2. Analysis of results. Management decisions } \\
\text { 4.3. Reports presentation } \\
\text { 4.5. Proposal of case studies supported by the simulator. }\end{array}$ \\
\hline
\end{tabular}

Source: own elaboration

- Perform semiannual planning such as: Syllabus, analytical program, and class plan, among others, in accordance with the policy of each institution.

- Build educational resources such as videos, presentations, workshops, and forums among others for each planned unit.

- Design a diagnostic instrument on previous knowledge of business simulation aimed at students.

\section{Stage 4. Execution of simulator planning}

- Apply the diagnostic instrument to students to strengthen teaching-learning strategies.

- Address sequentially planned units accompanied by the class plan.

- Refine the class plan and educational resources.

- Use a didactic procedure in which students apply the use of the simulator.

\section{Stage 5. Evaluation and action control}

- Conduct an accompanying workshop with the participants to gather their opinions about each stage of the program.

- Conduct class observations to professors and students to assess performance in the use of business simulators.

- Apply an instrument to know the degree of satisfaction of teachers and students in the use of the business simulator (IADOV is suggested).

- Verify that the personnel in charge fully transmitted the semiannual planning to students.

- Analyze the overall results for continuous improvement.

\section{Conclusions}

This research makes available to the HEIs an alternative that breaks the teaching-learning paradigms traditionally 
used, higher education institutions that have the responsibility of training highly prepared professionals should consider this proposal in order to implement it as a strategy in their study program.

The research reflects that its use is fundamental in the teaching-learning process since it allows teachers to provide their students the opportunity to experience a new and dynamic simulated work environment through an appropriate methodology, so that they can prepare to face real situations in the business field and in working life, based on their experience with each of the elements.

The proposed strategy contributes to the use of the business simulator in the teaching-learning process in business administration or related careers. It is a valuable tool that allows enhancing teachers' and students' professional training skills. Finally, the methodological strategy comprises 5 stages that are constituted as follows: diagnosis, preparation, planning, execution, evaluation, and control.

\section{References}

Alqirem, R., \& Al Omoush, K. (2018). System Dynamics Simulator of Inventory Management as a Learning Tool to Improve Undergraduate's Decision Making. International Conference on Engineering, Project, and Product Management, 275-280. https://doi.org/10.1007/978-3-319-74123-9_29

Ballina, F., \& Marín, S. (2007). Las competencias profesionales con las TIC y el espíritu emprendedor. (S. G. Técnica, Ed.) Ministerio de educación y ciencia secretaría general de educación. Retrieved August 12, 2019, from http://bit.ly/2KFDSZ1

Barcia, J., \& Carvajal, B. (2015). El proceso de enseñanza aprendizaje en la educación superior. REFCalE, 3(3), 139-154. Retrieved October 3, 2019, from www.refcale.uleam.edu.ec/index.php/refcale/article/view/57

CEO-VIRTUAL. (2014). ceo-virtual.com. Retrieved from https://www.ceo-virtual.com

Chavarro, M., \& Ramírez, A. (2009). Importancia de la implementación de tecnologías de información y herramientas. Universidad de la Salle. Bogotá: Ciencia Unisalle.

Consejo de Educación Superior. (2018). Ley Orgánica de Educación Superior. Quito, Pichincha, Ecuador: Registro Oficial Suplemento 297. Retrieved August 7, 2019, from http://bit.ly/2yNxQzW

Da Cruz, R. (2017). Gestión académica universitaria para el desempeño del profesor en el proceso de enseñanza-aprendizaje. Universida de Matanzas. La Habana: Editorial Universitaria del Ministerio de Educación Superior de la República de Cuba. Retrieved October 3, 2019, from https://ebookcentral.proquest.com/lib/utasp/reader.action?docID=5045609\&ppg=1

Garizurieta, J., Muñoz, A. Y., Otero, A. D., \& González, R. Á. (2018). Simuladores de negocios como herramienta de enseñanza-aprendizaje en la educación superior. Scielo, X(2). Retrieved August 12, 2019, from http://bit.ly/2YQ0BqC

Garzón, M. (2012). Los simuladores de negocios como alternativa de desarrollo empresarial. Universidad Católica de Santiago de Guayaquil. Guayaquil: Universidad Católica de Santiago de Guayaquil.

Global2020. (2015). Retrieved from doi:bit.ly/2XEa5WY

Guzmán, A. P., \& Moral, M. E. (2018). Percepción de los universitarios sobre la utilidad didáctica de los simuladores virtuales en su formación. Revista de medios y educación, 53, 41-60. https://doi.org/10.12795/pixelbit.2018.i53.03

Joldoshov, M., \& Sayakbaeva, J. (2018). The Significance of Using Business Simulations in Training of Bachelors andMasters. Formación profesional docente en Asia Central. Educación y formación técnica y profesional: cuestiones, inquietudes y perspectivas., XXVIII. https://doi.org/10.1007/978-3-319-73093-6_11

LABSAG. (2018). Historia y Eficacia de la Simulación. LABSAG Simuladores de Negocios. Retrieved August 26, 2019, from http://bit.ly/2U5LHeP

Lainema, T. (1999). Planning Guidelines for Next Generation Business Simulation. IFIP-International Federation for Information Processing, XVII. https://doi.org/10.1007/978-0-387-35393-7_3

León, E., \& Cañas, F. (2014). Modelos de simulación en la Escuela de Administración de Negocios, UCR. Red de Revistas Científicas de América Latina, XV(31), 86-98. Retrieved September 12, 2019, from http://www.redalyc.org/articulo.oa?id=66631887007

Mendoza, F. (2016). Tutorial de la asignatura simulación gerencial a partir del simulador business global de company game. Universidad de la Salle . Bogotá: Ciencia Unisalle.

Michelsen Consulting. (2019). LABSAG Simuladores de Negocios. Obtenido de bit.ly/2ITAHUW 
Michelsen Consulting. (2018). TEMPOMATIC (Gerencia General Integral). LABSAG Simuladores de Negocios. Retrieved August 26, 2019, from http://bit.ly/337jGXc

Musarskaya, M., \& Kooli, K. (2017). The Role of Simulator Games in Marketing Education: Evidence from Academics in Bournemouth University. Creating Marketing Magic and Innovative Future Marketing Trends, 103-114. https://doi.org/10.1007/978-3-319-45596-9_21

Ochoa, A., González , S., Moriel, E., Arreola, J., \& García, F. (2017). Improving Decision-Making in a Business Simulator Using TOPSIS Methodology for the Establishment of Reactive Stratagems. Springer International Publishing. https://doi.org/10.1007/978-3-319-47054-2_55

Orellana, Á., \& Montenegro, E. (2015). Aproximación a una metodología para el uso de simuladores de negocios en el proceso de enseñanzaaprendizaje del Tecnólogo en Administración de Empresas. Santiago de Cuba, 47-69. Retrieved October 1, 2019, from http://repositorio.itb.edu.ec/handle/123456789/1150

Ruíz, S., \& Ruíz, J. A. (2013). uso del simulador de negocio como herramienta para el aprendizaje en alumnos de educación superior de la U.A.E.M. Revista de Estudios en Contaduría, Administración e Informática, II(3), 101-121. Retrieved August 26, 2019, from http://bit.ly/325wI7u

Tejada, P., Viñas, L., \& Arcos, L. (2016). Emprendimiento, Simulación y Globalización como bases en la formación del ingeniero del siglo XXI. ANFEI DIGITAL, 1-10. Retrieved October 1, 2019, from bit.ly/2nxisWs

\section{Copyrights}

Copyright for this article is retained by the author(s), with first publication rights granted to the journal.

This is an open-access article distributed under the terms and conditions of the Creative Commons Attribution license (http://creativecommons.org/licenses/by/4.0/). 